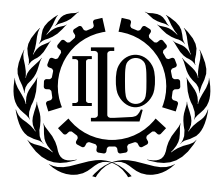

International

Labour

Office

Working Paper No. 5 / 2015

Geneva

\title{
Domestic work, wages, and gender equality: Lessons from developing countries
}

Martin Oelz and Uma Rani

Gender,

Equality

and Diversity

Branch 


\section{Domestic work, wages, and gender equality: lessons from developing countries}

Martin Oelz and Uma Rani 
Copyright @ International Labour Organization 2015

First published 2015

Publications of the International Labour Office enjoy copyright under Protocol 2 of the Universal Copyright Convention. Nevertheless, short excerpts from them may be reproduced without authorization, on condition that the source is indicated. For rights of reproduction or translation, application should be made to ILO Publications (Rights and Licensing), International Labour Office, CH-1211 Geneva 22, Switzerland, or by email: rights@ilo.org. The International Labour Office welcomes such applications.

Libraries, institutions and other users registered with a reproduction rights organization may make copies in accordance with the licences issued to them for this purpose. Visit www.ifrro.org to find the reproduction rights organization in your country.

Oelz, Martin; Rani, Uma

Domestic work, wages, and gender equality: lessons from developing countries / Martin Oelz and Uma Rani; International Labour Office, Gender, Equality and Diversity Branch (GED). - Geneva: ILO, 2015

(Working paper ; No. 5/2015)

ISBN: 978-92-2-130350-3 (print)

ISBN: 978-92-2-130351-0 (web pdf)

International Labour Office. Gender, Equality and Diversity Branch.

domestic work / women workers / labour market / minimum wage / sex discrimination / labour standards / compliance / role of ILO / developing countries

08.17 .1

ILO Cataloguing in Publication Data

The designations employed in ILO publications, which are in conformity with United Nations practice, and the presentation of material therein do not imply the expression of any opinion whatsoever on the part of the International Labour Office concerning the legal status of any country, area or territory or of its authorities, or concerning the delimitation of its frontiers.

The responsibility for opinions expressed in signed articles, studies and other contributions rests solely with their authors, and publication does not constitute an endorsement by the International Labour Office of the opinions expressed in them.

Reference to names of firms and commercial products and processes does not imply their endorsement by the International Labour Office, and any failure to mention a particular firm, commercial product or process is not a sign of disapproval.

ILO publications and digital products can be obtained through major booksellers and digital distribution platforms, or ordered directly from ilo@turpin-distribution.com. For more information, visit our website: www.ilo.org/publns or contact ilopubs@ilo.org. 


\section{Table of contents}

Executive summary

1. Introduction

1

2. Women's participation rates and gender wage gaps

3. The case of domestic workers

Regulating wages in domestic work ....................... 13

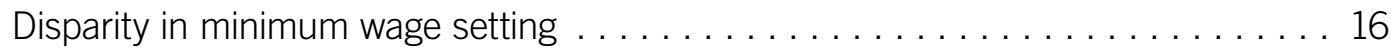

Extent of minimum wage compliance and extent of violation............. 17

Designing minimum wage coverage for domestic workers. . . . . . . . . . . . 20

Improving compliance................................ 21

4. Concluding considerations 25

References ...................................... 27

Annex: Data sources and time period per country ............... 31 


\section{Executive summary ${ }^{1}$}

The ILO Domestic Workers Convention, 2011 (No. 189) calls for inclusion of domestic workers into minimum wage coverage and for effective measures for ensuring compliance. This paper seeks to contribute to a better understanding of developments regarding labour market participation and remuneration in the domestic work sector in comparison with other sectors, drawing on latest available household and labour surveys data and legal information from a diverse group of developing countries (Brazil, Costa Rica, India, Indonesia, Mali, Mexico, Peru, Philippines, South Africa, Turkey, and Viet Nam).

The paper looks at the basic characteristics of female domestic workers, gaps in minimum wage coverage, compliance, and the extent of minimum wage violations. Presenting empirical evidence on labour market inequality along gender lines, the paper discusses the role of minimum wages for reducing gender disparity and questions of regulatory design. Finally, the paper examines strategies for compliance and enforcement, arguing that there is a need for comprehensive and innovative approaches in order to ensure respect for minimum wage legislation in the domestic work sector. It concludes that minimum wages for domestic workers are indeed an important tool for promoting gender equality within a broader approach to addressing informality and worker's empowerment.

The paper was presented at the Labour Law Research Network Conference, Amsterdam, 25-27 June 2015 and the Regulating Decent Work Conference; Geneva, 8-10 July 2015. The authors welcome feedback at oelz@ilo.org and amara@ilo. org. 


\section{Introduction}

The position of women in the labour market tends to be characterized by their over-representation in low paid jobs in economic sectors or occupations in which women are concentrated. Domestic work is one of the sectors that is probably among the lowest paying jobs in the labour market. A number of reasons have been identified for the low remuneration of domestic work which include: low formal skills and educational levels, high incidence of informality, lack of collective representation, weak individual bargaining power, lack of possibilities for income generation and vulnerable social status. Another factor is the gender-based undervaluation of domestic work, as these workers also perform the traditional role of care and household tasks (unpaid work) within their own households. Globally, about 42.5 per cent of the world's domestic workers do not enjoy minimum wage coverage despite the fact that in the countries in which they work minimum wages are set for other workers (ILO, 2013a). Seeking to address this situation, the ILO Domestic Workers Convention, 2011 (No. 189) calls for inclusion of domestic workers into minimum wage coverage and effective measures for ensuring compliance. ${ }^{2}$ Since then, several countries have included domestic workers under minimum wage coverage to address low pay among these workers, while others have not done so.

This paper seeks to contribute to a better understanding of developments as regards labour market participation and remuneration in the domestic work sector in comparison with other sectors, drawing on available household and labour surveys data and legal information from a diverse group of developing countries (Brazil, Costa Rica, India, Indonesia, Mali, Mexico, Peru, Philippines, South Africa, Turkey, and Viet Nam) for two time periods in the past decade. It then specifically looks at the basic characteristics of female domestic workers, gaps in minimum wage coverage, compliance, and the extent of minimum wage violations. Presenting empirical evidence on labour market inequality along gender lines, the paper discusses the role of minimum wages for reducing gender disparity and questions of regulatory design.

The paper's economic analysis is linked to the prevailing regulatory framework, looking both at countries that have - in different ways - set minimum wages for domestic workers, as well as some which either have not set minimum wages or have done so only partially. Where minimum wages for domestic workers are in force, the focus is placed on compliance gaps, while for the remaining countries the paper makes an attempt to identify possible policy options for

\footnotetext{
As of 1 October 2015, ratifications of the Convention by 22 ILO member States were registered. Among the ratifying countries, 12 are from Latin America and the Caribbean (Argentina, the Plurinational State of Bolivia, Chile, Colombia, Costa Rica, Dominican Republic, Ecuador, Guyana, Nicaragua, Panama, Paraguay and Uruguay); 7 from Europe (Belgium, Finland, Germany, Ireland, Italy, Portugal and Switzerland); 2 from Africa (Mauritius and South Africa); and 1 from Asia (Philippines). No country from the Arab region has ratified the Convention. Up-dates information on ratifications can be found at the ILO's NORMLEX database (www.ilo.org/normlex).
} 
minimum wage extension based on the experiences in minimum wage countries. Finally, the paper examines strategies for compliance and enforcement, arguing that there is a need for comprehensive, innovative approaches in order to ensure respect for minimum wage legislation. It concludes that minimum wages for domestic workers are indeed an important tool for promoting gender equality within a broader approach to addressing informality and workers' empowerment. 


\section{Women's participation rates and gender wage gaps}

Women's labour force participation rates have been quite varied across the world. Within Asia, Africa and Latin America, the participation rates have been quite varied both within and between regions with varying degrees of quality of employment. There is also undervaluation of women's work and in some countries participation rates might be high but a large proportion of them might be underemployed or engaged in activities that are not accounted, as they are not monetarily remunerated. The variations in female participation rates and the gender gaps in participation have been well documented (Ganguli et al., 2014). In their analysis for select 39 advanced and developing countries for the age group 35 to 44 years they find that female labour force participation rates in Ghana, Kenya and South Africa were quite similar to those in the advanced economies. Female participation rates in some of the Asian countries (Cambodia, China, Mongolia and Viet Nam) were also quite high and the participation gap below 20 per cent, while in some others (India, Malaysia, Philippines) the gap is almost 50 per cent. In Latin American countries the participation gap ranges between 29 per cent in Argentina to 53 per cent in Costa Rica. The gap is found to be highest in some of the Arab countries where it is above 60 per cent (Ganguli et al., 2014).

These participation rates are quite similar to what we observe for a sample of select developing countries for the age group 15 to 64 years. Female participation rates are lower than for males in all countries, for both rural and urban areas (table 1). The gaps in participation rates have declined over the past decade in all countries except India and Viet Nam. For the most recent year available, within Latin America, the participation gap varies between 13 per cent (Peru) and 31 per cent (Costa Rica). In Asia it ranges between 7.5 per cent (Viet Nam) and 48.2 per cent (India), and it is even higher in urban areas. In India, female participation rates have been declining over the past decades and a number of reasons such as increased enrolment in education, income effect, and methodological issues have been identified, all of which continue to remain open for scrutiny (Kapsos et al, 2014). A marginal decline in participation rates are also observed in South Africa and Viet Nam. In Africa the participation gaps are low, but the participation rates are quite high in Mali and comparatively low in South Africa. The huge increase in female participation rates in Mali is found to be in the rural agricultural sector and most of it being unpaid. ${ }^{3}$ The gap in the participation rates in Turkey is quite high, which could be due to the cultural factor.

In most countries except Brazil, Peru and Viet Nam the participation rates are less than 50 per cent. Along with comparatively lower female participation rates, female workers also tend to be concentrated in the informal sector (informal wage work, self-employed and as unpaid family helpers), though there are some variations across countries (table 2). The proportion of female workers employed as formal waged workers is small, except in Brazil and South Africa where the proportions are comparatively high, and in Philippines and Turkey where it is around 40 per cent. In about 50 per cent of the countries under analysis, more than

It is possible that the increase in participation rate in Mali is a statistical artifact, in the sense that the survey captured these workers much better in the latest round. 
Table 1: Labour force participation rates and gaps in select developing economies, age group15-64 years

\begin{tabular}{|c|c|c|c|c|c|c|c|c|c|c|c|c|}
\hline & \multicolumn{6}{|c|}{ mid-2000s } & \multicolumn{6}{|c|}{ Latest year available } \\
\hline & \multicolumn{2}{|l|}{ All } & \multicolumn{2}{|l|}{ Rural } & \multicolumn{2}{|l|}{ Urban } & \multicolumn{2}{|l|}{ All } & \multicolumn{2}{|l|}{ Rural } & \multicolumn{2}{|l|}{ Urban } \\
\hline & Female & Gaps & Female & Gaps & Female & Gaps & Female & Gaps & Female & Gaps & Female & Gaps \\
\hline Brazil & 55.3 & 24.2 & 63.7 & 26.5 & 53.8 & 23.4 & 56.4 & 23.3 & 58.7 & 28.7 & 56.0 & 22.2 \\
\hline Costa Rica & 40.6 & 39.6 & 48.7 & 38.9 & 60.0 & 23.6 & 45.6 & 31.2 & 35.4 & 42.3 & 51.2 & 25.1 \\
\hline India & 43.6 & 41.0 & 50.8 & 36.1 & 23.8 & 55.2 & 33.2 & 48.2 & 38.7 & 44.4 & 19.3 & 57.9 \\
\hline Indonesia & 42.6 & 36.1 & 47.3 & 35.5 & 36.7 & 36.6 & 48.2 & 30.7 & 45.0 & 29.0 & 50.9 & 31.9 \\
\hline Mali & 39.2 & 27.5 & 38.0 & 31.5 & 41.6 & 20.2 & 67.9 & 11.0 & 76.0 & 7.8 & 42.8 & 21.9 \\
\hline Mexico & 38.7 & 36.3 & - & - & - & - & 40.9 & 32.4 & - & - & - & - \\
\hline Peru & 61.9 & 15.9 & 81.2 & 9.1 & 55.7 & 17.6 & 69.9 & 13.0 & 85.2 & 4.5 & 65.5 & 15.2 \\
\hline Philippines & 45.8 & 28.5 & - & - & - & - & 47.2 & 24.0 & - & - & - & - \\
\hline $\begin{array}{l}\text { South } \\
\text { Africa }\end{array}$ & 36.6 & 14.9 & - & - & - & - & 34.6 & 12.8 & 21.6 & 9.0 & 41.7 & 14.0 \\
\hline Turkey & 23.7 & 44.5 & 34.9 & 36.6 & 17.1 & 49.2 & 27.8 & 41.5 & 40.4 & 32.9 & 22.5 & 45.1 \\
\hline Viet Nam & 78.1 & 4.9 & 82.4 & 3.0 & 68.3 & 9.0 & 76.9 & 7.5 & 81.8 & 5.7 & 67.2 & 10.8 \\
\hline
\end{tabular}

Source: Authors' estimates based on household and labour force surveys of the respective country.

one-fourth of the women are employed as unpaid family helpers, that is helping their parents or spouse without any remuneration. Across countries, Mali has a very high proportion of unpaid family helpers for both among men and women, which is due to the dominance of the agricultural sector where the majority are employed and work as unpaid family workers on their farms. India, Indonesia, Peru and Turkey also exhibit a very high proportion of female unpaid family helpers due to a large agricultural sector and a high incidence of self-employed activities. As a result, most women do not have any income despite working, and they do not have access to social security benefits. Even when employed with remuneration, women tend to be hired on an informal or temporary basis without any proper contracts, social security benefits, etc., as is observed in the case of India, South Africa and Viet Nam. Among the three countries (Brazil, Peru and Viet Nam), which exhibit high participation rates, only Brazil has a large proportion of women engaged in formal wage work, while in the latter two they are engaged in informal wage work, in self-employment or unpaid family worker (table 2).

There are regional variations with regard to the distribution of workers across industry groups, according to the data available for the latest year. In the Latin American countries, more than 
Table 2: Proportion of workers by employment status, all workers, latest year available

\begin{tabular}{|c|c|c|c|c|c|c|c|c|c|c|}
\hline & \multicolumn{5}{|l|}{ Females } & \multicolumn{5}{|l|}{ Males } \\
\hline & $\begin{array}{l}\text { Formal } \\
\text { wage } \\
\text { workers }\end{array}$ & $\begin{array}{l}\text { Informal } \\
\text { wage } \\
\text { workers }\end{array}$ & $\begin{array}{l}\text { Self- } \\
\text { employed }\end{array}$ & Employer & $\begin{array}{l}\text { Unpaid } \\
\text { family } \\
\text { helper }\end{array}$ & $\begin{array}{l}\text { Formal } \\
\text { wage } \\
\text { workers }\end{array}$ & $\begin{array}{l}\text { Informal } \\
\text { wage } \\
\text { workers }\end{array}$ & $\begin{array}{l}\text { Self- } \\
\text { employed }\end{array}$ & Employer & $\begin{array}{l}\text { Unpaid } \\
\text { family } \\
\text { helper }\end{array}$ \\
\hline Brazil & 53.1 & 18.0 & 6.0 & 17.1 & 5.9 & 62.4 & 4.5 & 8.0 & 22.5 & 2.6 \\
\hline $\begin{array}{l}\text { Costa } \\
\text { Rica }\end{array}$ & 24.9 & 22.9 & 3.4 & 47.0 & 1.8 & 44.3 & 19.3 & 14.2 & 19.6 & 2.5 \\
\hline India & 10.4 & 36.8 & 16.9 & 0.5 & 35.3 & 18.4 & 32.8 & 36.0 & 1.3 & 11.6 \\
\hline Indonesia & 27.4 & 7.6 & 17.9 & 13.4 & 33.8 & 29.8 & 13.3 & 21.1 & 23.7 & 12.1 \\
\hline Mali & 2.0 & 2.7 & 44.8 & 0.9 & 49.6 & 5.4 & 8.0 & 58.1 & 2.4 & 26.1 \\
\hline Mexico* & & 7.0 & 17.6 & 7.1 & 8.3 & & 8.5 & 15.2 & 11.7 & 4.6 \\
\hline Peru & 22.8 & 15.7 & 33.4 & 3.0 & 25.1 & 22.0 & 29.6 & 31.6 & 7.4 & 9.3 \\
\hline Philippines & 40.5 & 14.7 & 27.6 & 2.4 & 14.8 & 39.8 & 18.5 & 28.2 & 4.8 & 8.7 \\
\hline $\begin{array}{l}\text { South } \\
\text { Africa }\end{array}$ & 54.0 & 32.0 & 10.1 & 2.8 & 1.2 & 54.9 & 28.5 & 8.6 & 7.5 & 0.5 \\
\hline Turkey & 46.7 & 6.2 & 11.2 & 1.2 & 34.6 & 59.1 & 8.3 & 21.1 & 6.7 & 4.9 \\
\hline Viet Nam & 14.2 & 52.1 & 20.0 & 0.7 & 13.0 & 19.6 & 62.7 & 11.9 & 1.0 & 4.8 \\
\hline
\end{tabular}

65 per cent of the female employment is in the services sector; and manufacturing absorbs less than 15 per cent of female employment. Within the services sector, women in Brazil and Costa Rica are much more equally distributed between low-skilled and high-skilled services, while one-fourth are engaged as domestic workers. In Mexico and Peru, women are largely in low-skilled services, and about one-fifth are engaged as domestic workers. The services sector is also where most of the men are employed, though the proportions are comparatively smaller, as men are also working in manufacturing, agriculture and construction (table 3 ). In the Asian region, the female employment across industry groups is quite varied: in India, a large proportion of women work in agriculture and allied activities; in Indonesia and Viet Nam women are largely engaged in agriculture and low-skilled services sector; while in the Philippines, women are more concentrated in low-skilled services, especially as domestic workers. In Mali, women are largely engaged in agriculture (50 per cent) and in low skilled services (35 per cent), while in South Africa women mostly work in the services sector, both in low-skilled and high-skilled services. In most of the countries women are underrepresented compared to men in the manufacturing sector and they comprise about 15 per cent in Indonesia, Mexico, Turkey and Viet Nam (table 3). Within the low-skilled services 
Table 3: Distribution of workers across industry groups, Males and Females, latest year available

\begin{tabular}{|c|c|c|c|c|c|c|c|c|}
\hline & Agriculture & Mining & Manufacturing & Construction & $\begin{array}{l}\text { Low-skilled } \\
\text { services }\end{array}$ & $\begin{array}{l}\text { High-skilled } \\
\text { services }\end{array}$ & $\begin{array}{l}\text { Domestic } \\
\text { workers }\end{array}$ & $\begin{array}{l}\text { All } \\
\text { workers }\end{array}$ \\
\hline \multicolumn{9}{|l|}{ Males } \\
\hline Brazil & 18.5 & 0.7 & 16.1 & 13.0 & 32.3 & 18.5 & 0.9 & 100 \\
\hline Costa Rica & 19.5 & 0.1 & 15.7 & 9.8 & 33.9 & 20.1 & 0.9 & 100 \\
\hline India & 45.9 & 0.8 & 11.7 & 11.7 & 21.4 & 8.0 & 0.5 & 100 \\
\hline Indonesia & 38.6 & 1.6 & 11.7 & 8.5 & 30.1 & 8.6 & 0.9 & 100 \\
\hline Mali & 70.5 & 0.9 & 6.7 & 2.8 & 12.0 & 6.5 & 0.5 & 100 \\
\hline Mexico & 17.3 & 0.6 & 21.2 & 12.7 & 29.9 & 17.6 & 0.6 & 100 \\
\hline Peru & 26.2 & 2.0 & 12.0 & 10.0 & 32.9 & 16.7 & 0.3 & 100 \\
\hline Philippines & 39.4 & 0.9 & 8.8 & 9.2 & 29.2 & 11.1 & 1.5 & 100 \\
\hline South Africa & 5.5 & 3.7 & 16.5 & 12.5 & 32.6 & 25.8 & 3.3 & 100 \\
\hline Turkey & 17.1 & 0.7 & 21.4 & 9.7 & 32.2 & 18.8 & 0.2 & 100 \\
\hline Viet Nam & 44.7 & 0.9 & 14.0 & 11.5 & 19.7 & 9.2 & 0.1 & 100 \\
\hline \multicolumn{9}{|l|}{ Females } \\
\hline Brazil & 10.9 & 0.1 & 12.5 & 0.5 & 29.4 & 29.3 & 17.2 & 100.0 \\
\hline Costa Rica & 4.4 & 0.0 & 10.4 & 0.8 & 33.5 & 32.5 & 18.4 & 100.0 \\
\hline India & 68.3 & 0.3 & 10.9 & 5.3 & 6.5 & 7.1 & 1.6 & 100.0 \\
\hline Indonesia & 37.9 & 0.3 & 14.4 & 0.3 & 32.7 & 10.0 & 4.4 & 100.0 \\
\hline Mali & 52.2 & 0.3 & 8.3 & 0.2 & 24.7 & 3.4 & 10.8 & 100.0 \\
\hline Mexico & 3.5 & 0.1 & 15.5 & 0.7 & 42.0 & 27.4 & 10.8 & 100.0 \\
\hline Peru & 24.0 & 0.3 & 9.8 & 0.3 & 43.0 & 16.1 & 6.5 & 100.0 \\
\hline Philippines & 20.0 & 0.1 & 9.2 & 0.3 & 39.5 & 18.0 & 13.0 & 100.0 \\
\hline South Africa & 3.5 & 0.6 & 10.6 & 2.0 & 30.9 & 37.5 & 14.9 & 100.0 \\
\hline Turkey & 40.9 & 0.0 & 14.7 & 0.8 & 16.7 & 23.8 & 3.1 & 100.0 \\
\hline Viet Nam & 49.9 & 0.3 & 15.4 & 1.3 & 22.8 & 9.6 & 0.7 & 100.0 \\
\hline
\end{tabular}

Source: Authors' estimates based on household and labour force surveys of the respective country. 
sector women are largely concentrated in trade, social and personal community services. These sectors were traditionally dominated by women and there has been no major change in occupational segregation despite economic development and high rates of economic growth in many of these countries, except Brazil and Costa Rica. A high proportion of women also work as domestic workers in all the countries under analysis compared to men.

The entry of a large number of women into the labour force has provided them with certain rights and integration into society, yet it has not necessarily translated into equal pay for work of equal value (Abramo and Valenzuela, 2005), and respect for all forms of jobs performed by women, and there continues to be some form of discrimination and undervaluation in terms of wages for certain tasks performed by women. A number of studies exploring the factors behind the gender wage gap have found that even after controlling for education, age, job tenure, occupation and other labour market characteristics, the gender gap in remuneration continues to persist (ILO, 2009, 2014a; UNDP, 2013; Rubery and Grimshaw, 2011), though the gap has been narrowing in recent years for reasons that remain unclear.

A recent analysis based on 40 advanced and developing countries shows that women have lower average annual incomes than men: on average, women earned between 57 per cent (Switzerland) and 97 per cent (Philippines) of what men earned (Rani et al., 2015). The study showed that compared to the mid-2000s, the gender gap in the average annual incomes has decreased in almost all the countries under analysis by between one (Bulgaria, Czech Republic, France, Greece, Italy, Slovakia) and eight (Lithuania, Luxembourg) percentage points. The gender gap increased in only four countries (Iceland, Malta, Poland, Viet Nam) under analysis by between one and five percentage points. These findings are consistent with ILO (2014a), where women's average wages are found to be between 4 and 36 per cent lower than men's. The gender wage gaps in Latin America were found to be declining over the past decade, which is consistent with other studies (Nopo and Hoyos, 2010).

The analysis for the 11 developing countries also shows a narrowing of the gender wage gap in all countries except Costa Rica. In most of the countries the gap has reduced by more than four percentage points, which could be due to the implementation of minimum wages for low paid workers in some of these countries. However, it is possible that the average wages of the male workers are declining, which could also lead to the narrowing of the gender wage gap. Despite the narrowing, the gender wage gap persists: in Mali, women in general earn 50 per cent of men's earnings and in all other countries women earn between 60 and 90 per cent of men's wages. In the Philippines women earn almost as much as men, which has also been found in other studies mentioned above. In general, women earn less than men in agriculture, manufacturing, low-skilled services and high-skilled services sector (table 4).

If we compare the female wages across different sectors with the average female wages, we find that women engaged in agriculture and domestic work sector earn considerably less compared to those in other sectors in all countries for the most recent year (table 5). The trend has remained quite stable over the past decade, but in some countries the average wages for domestic workers are falling. This very clearly indicates that these two sectors are quite vulnerable regarding the remuneration of workers, especially for females. In this papers we focus on one of these vulnerable groups, notably the domestic workers. 
Table 4: Ratio of female to male average wages in different industry groups

\begin{tabular}{|c|c|c|c|c|c|c|c|c|}
\hline & Agriculture & Mining & Manufacturing & Construction & $\begin{array}{l}\text { Low-skilled } \\
\text { services }\end{array}$ & $\begin{array}{l}\text { High-skilled } \\
\text { services }\end{array}$ & $\begin{array}{l}\text { Domestic } \\
\text { workers }\end{array}$ & $\begin{array}{l}\text { All } \\
\text { workers }\end{array}$ \\
\hline \multicolumn{9}{|l|}{ Mid-2000s } \\
\hline Brazil & 0.58 & 1.02 & 0.56 & 1.58 & 0.67 & 0.68 & 0.73 & 0.71 \\
\hline Costa Rica & 0.78 & 0.76 & 0.60 & 0.91 & 0.66 & 0.84 & 0.55 & 0.76 \\
\hline India & 0.63 & 0.29 & 0.42 & 0.68 & 0.95 & 0.68 & 0.55 & 0.53 \\
\hline Indonesia & 0.52 & 0.42 & 0.59 & 1.25 & 0.74 & 0.84 & 0.50 & 0.71 \\
\hline Mali & 0.43 & 0.19 & 0.27 & 1.41 & 0.42 & 0.73 & 0.54 & 0.41 \\
\hline Mexico & 0.88 & 0.94 & 0.60 & 1.44 & 0.59 & 0.80 & 0.62 & 0.73 \\
\hline Peru & 0.65 & 1.69 & 0.67 & 1.70 & 0.84 & 0.74 & 0.51 & 0.72 \\
\hline Philippines & 0.82 & 0.76 & 0.89 & 1.31 & 0.89 & 1.10 & 0.61 & 1.00 \\
\hline South Africa & 0.71 & 1.33 & 0.61 & 1.13 & 0.66 & 0.75 & 0.77 & 0.72 \\
\hline Turkey & 0.61 & 1.49 & 0.80 & 0.85 & 1.27 & 0.93 & 1.19 & 0.83 \\
\hline Viet Nam & 0.70 & 0.63 & 0.68 & 0.87 & 0.77 & 1.00 & 0.88 & 0.75 \\
\hline \multicolumn{9}{|c|}{ Latest year available } \\
\hline Brazil & 0.67 & 1.00 & 0.58 & 1.54 & 0.66 & 0.68 & 0.67 & 0.71 \\
\hline Costa Rica & 0.37 & 1.35 & 0.90 & 0.70 & 0.93 & 0.60 & 1.60 & 0.68 \\
\hline India & 0.67 & 0.58 & 0.51 & 0.69 & 0.82 & 0.66 & 0.54 & 0.60 \\
\hline Indonesia & 0.58 & 0.61 & 0.64 & 1.46 & 0.75 & 0.81 & 0.55 & 0.76 \\
\hline Mali & 0.46 & 1.10 & 0.48 & 0.42 & 0.68 & 0.96 & 0.99 & 0.51 \\
\hline Mexico & 0.87 & 1.14 & 0.67 & 1.20 & 0.64 & 0.83 & 0.63 & 0.77 \\
\hline Peru & 0.62 & 0.75 & 0.69 & 1.02 & 0.63 & 0.83 & 0.70 & 0.72 \\
\hline Philippines & 0.87 & 1.39 & 0.92 & 1.30 & 0.85 & 1.10 & 0.70 & 0.99 \\
\hline South Africa & 0.63 & 0.93 & 0.75 & 0.75 & 0.76 & 0.81 & 0.76 & 0.78 \\
\hline Turkey & 0.68 & 0.84 & 0.81 & 1.11 & 0.91 & 0.88 & 0.68 & 0.93 \\
\hline Viet Nam & 0.77 & 0.81 & 0.75 & 0.88 & 0.80 & 0.94 & 1.10 & 0.85 \\
\hline
\end{tabular}


Table 5: Ratio of average wages of female workers in different industry groups to total average wages among female workers

\begin{tabular}{|c|c|c|c|c|c|c|c|}
\hline & Agriculture & Mining & Manufacturing & Construction & $\begin{array}{l}\text { Low-skilled } \\
\text { services }\end{array}$ & $\begin{array}{l}\text { High-skilled } \\
\text { services }\end{array}$ & $\begin{array}{l}\text { Domestic } \\
\text { workers }\end{array}$ \\
\hline \multicolumn{8}{|l|}{ Mid-2000s } \\
\hline Brazil & 0.43 & 1.75 & 0.88 & 1.58 & 0.93 & 1.53 & 0.43 \\
\hline Costa Rica & 0.60 & 1.01 & 0.87 & 1.00 & 0.85 & 1.67 & 0.36 \\
\hline India & 0.46 & 0.97 & 0.96 & 0.80 & 1.95 & 3.26 & 0.72 \\
\hline Indonesia & 0.49 & 0.83 & 0.94 & 1.61 & 0.99 & 1.86 & 0.62 \\
\hline Mali & 0.72 & 1.88 & 0.66 & 3.41 & 1.21 & 3.10 & 0.39 \\
\hline Mexico & 0.56 & 2.19 & 0.83 & 1.85 & 0.85 & 1.55 & 0.55 \\
\hline Peru & 0.35 & 5.70 & 0.94 & 1.66 & 0.99 & 1.54 & 0.39 \\
\hline Philippines & 0.43 & 0.61 & 1.01 & 1.28 & 0.90 & 1.71 & 0.44 \\
\hline South Africa & 0.39 & 1.80 & 0.99 & 0.89 & 0.67 & 1.83 & 0.23 \\
\hline Turkey & 0.46 & 2.75 & 1.01 & 1.67 & 1.34 & 1.02 & 1.76 \\
\hline Viet Nam & 0.59 & 1.31 & 1.13 & 1.27 & 1.39 & 1.84 & 0.84 \\
\hline \multicolumn{8}{|c|}{ Latest year available } \\
\hline Brazil & 0.49 & 2.36 & 0.87 & 1.54 & 0.90 & 1.51 & 0.46 \\
\hline Costa Rica & 0.56 & 0.12 & 0.81 & 0.12 & 1.40 & 1.08 & 0.38 \\
\hline India & 0.48 & 1.34 & 1.05 & 0.77 & 1.48 & 2.87 & 0.63 \\
\hline Indonesia & 0.49 & 1.24 & 0.88 & 1.64 & 0.97 & 1.85 & 0.54 \\
\hline Mali & 0.95 & 1.89 & 0.89 & 1.27 & 1.04 & 1.65 & 0.46 \\
\hline Mexico & 0.56 & 2.78 & 0.86 & 1.48 & 0.84 & 1.56 & 0.58 \\
\hline Peru & 0.38 & 1.64 & 0.99 & 1.36 & 0.79 & 1.50 & 0.45 \\
\hline Philippines & 0.44 & 1.05 & 1.03 & 1.21 & 0.95 & 1.71 & 0.42 \\
\hline South Africa & 0.29 & 1.49 & 0.96 & 0.68 & 0.87 & 1.47 & 0.27 \\
\hline Turkey & 0.45 & 0.90 & 0.75 & 1.03 & 0.84 & 1.30 & 0.46 \\
\hline Viet Nam & 0.70 & 1.26 & 0.90 & 0.97 & 1.04 & 1.21 & 0.90 \\
\hline
\end{tabular}

Source: Authors' estimates based on household and labour force surveys of the respective country. 


\section{The case of domestic workers}

Domestic workers have traditionally lacked recognition as "real" workers and this is deeply rooted in the perceptions and behaviour of employing households and society at large. In some of the countries under analysis, domestic workers largely belong to particular ethnic communities or social groups, like African Blacks in South Africa, or Scheduled castes or tribes in India. However, in others the composition of the workforce in the sector is much more mixed: in Brazil over 60 per cent of the domestic workers are of African descent (classified either as Black or Parda), while roughly one-third of them are classified as White; in Peru majority of the domestic workers are classified as White, while the others are mostly of indigenous or mestizo communities. In Viet Nam domestic workers are less represented in minority ethnic communities but belong to the most dominant community, the ethnic Khin group (table 6). While the ethnic composition of the workforce in the domestic work sector varies by country, domestic workers tend to be from disadvantaged communities, with disadvantage often but not always having an ethnic dimension. While an in-depth discussion of the reasons for the ethnic composition of the domestic work sector in particular countries goes beyond the scope of this paper, plausible reason for this are the high poverty rates among disadvantaged ethnic communities, historical factors related to slavery or rigid systems of social stratification along ethnic, caste, or religious lines, or the economic and social status of the employers and social stigma associated with certain ethnic groups or tasks performed by domestic workers.

In most of the countries domestic workers are either illiterate (India, Mali) or with primary education (Costa Rica, Indonesia, Mexico, Turkey and Viet Nam). While, in Brazil, Peru, Philippines and South Africa a sizeable proportion of female domestic workers have secondary education. The proportion of domestic workers who have a higher degree is quite negligible with the exception of the Philippines (9 per cent) (table 6). Due to their low levels of education, the skills of domestic workers are often not recognized and their tasks are seen as being of simple and routine nature. The capacity to perform these tasks is perceived as "innate", as they mirror work that has traditionally been carried out by women in their own homes. It is often also looked down upon as having no economic value, which often undermines their social and economic status within the society. As a result, the undervaluation of domestic work leads to low pay levels, despite the actual skills involved and the fact that a large majority of the female workforce is able to participate in the labour market due to the existence of domestic help. In addition, many domestic workers carry the burden of "dual responsibilities" at home - cleaning, cooking, and caring for the young and old - while at the same time doing similar tasks for other households to ensure a living for their families.

Low wages in domestic work are linked to lack of working time arrangements, with earnings often unrelated to actual hours worked, particularly in the case of live-in workers or when the pay is based on tasks rather than on time. Furthermore, there has historically been a prevalence of in-kind compensation in the form of food and accommodation. Providing for the domestic workers' welfare through granting such basic necessities rather than paying a wage which enables a decent living for the worker and her family has been and often continues to be the prevailing approach in many parts of the world. However, the frequent practice 
Table 6: Distribution of domestic workers by ethnic groups and education levels, latest available year

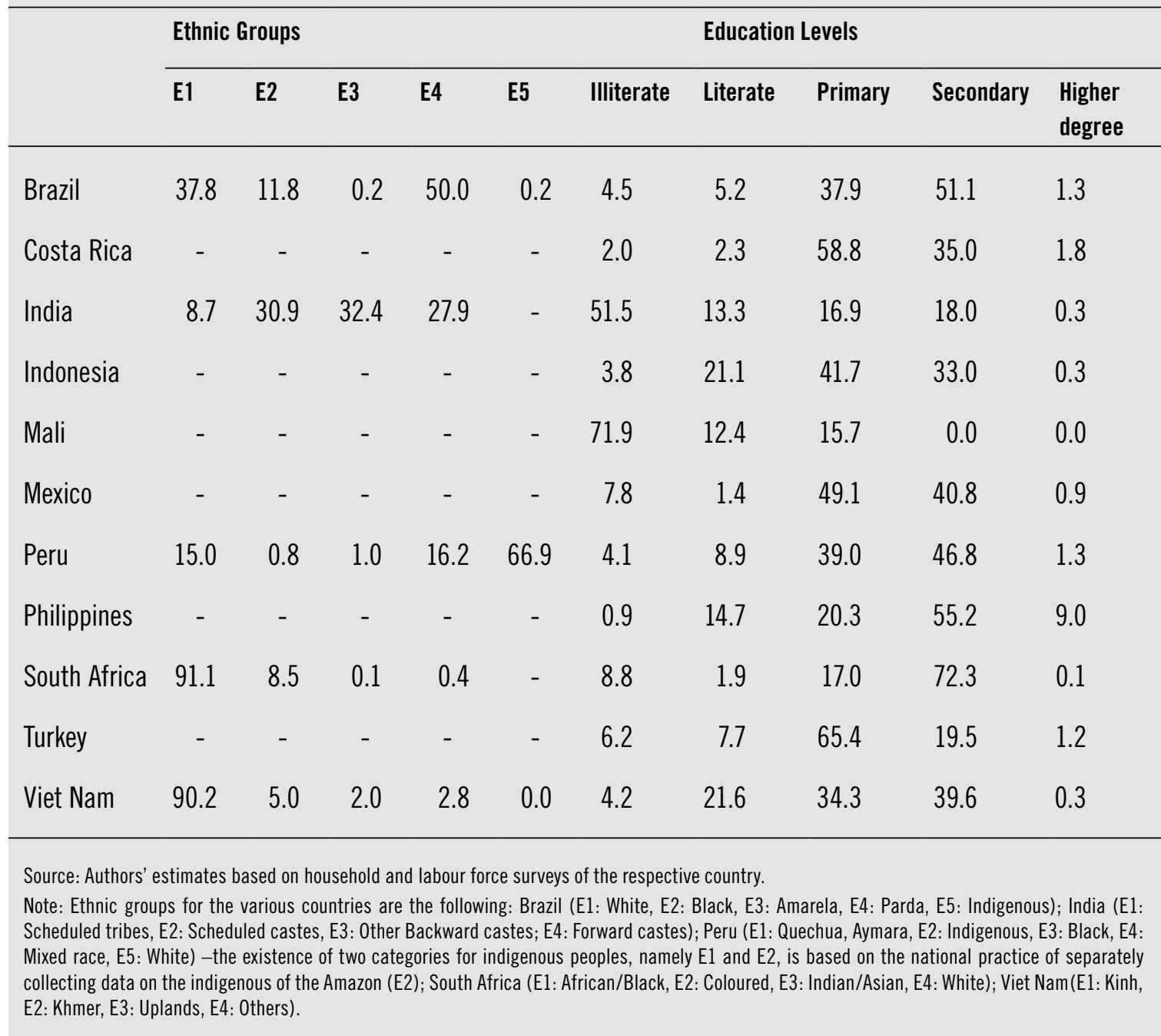

of unregulated in-kind allowance contributes to undervaluation and downward pressure on domestic workers' wages.

Though the domestic workers' movement has been growing in strength, including in developing countries, collective bargaining for improving their wages and working conditions remains an exception. Migrant workers often make up a large share of workers in the domestic work sector, including in countries such as Costa Rica, South Africa or Turkey, and they face additional vulnerabilities to abuse and exploitation. The level of illiteracy among domestic workers is quite high and there is a very high prevalence of informality. While the demand for domestic work is growing, they continue to struggle for basic rights such as minimum wages, equal pay for work of equal value, and better working and living conditions as there are no appropriate policy interventions. In many countries, there is still an absence of public policy focus on domestic workers, despite the positive developments in a growing number of countries since the passing of the ILO Domestic Worker Convention (No. 189) in 2011 and its supplementing Recommendation (No. 201). 


\section{Regulating wages in domestic work}

In general labour law coverage for domestic workers has historically been weak and minimum wage regulation has been even more so. An ILO survey of national laws on domestic work published in 1971 noted that only 20 out 68 countries that had replied to the survey had legislation fixing a minimum wage rate for domestic workers in private households. Twelve of these countries were in Africa, while "elsewhere the determination of the wage is left to the free determination of the parties and the free market forces" (ILO, 1970, p. 28). In 2008, during the preparation of the ILO standard-setting on domestic workers it was found that out of 66 countries, only two-third had minimum wage legislations for domestic worker (ILO, 2010). A very small group of countries regulate wages through collective bargaining agreements for domestic workers. ${ }^{4}$ Though there has been an increase in the number of countries having minimum wage legislation for domestic workers, still a large proportion of the global labour force in this sector remain without such protection. According to ILO estimates, some 42.5 per cent of domestic workers globally did not enjoy minimum wage coverage in 2010 , although the countries where they lived and worked did set minimum wages for other workers. Another 5.9 per cent of the domestic workers were covered by a minimum wage, but at a lower level than other workers. The highest level of exclusion from minimum wage coverage for domestic workers was found in the Arab region and in Asia and the Pacific (ILO, 2013a). ${ }^{5}$

Given that domestic work is growing in both the developing and advanced countries, and that large proportions of domestic workers are women from disadvantaged social or ethnic groups, and migrant workers who are vulnerable to labour exploitation, the question of effective regulation of domestic workers' wages requires further attention (see e.g. FRA, 2011; Shree 2012; Society for Regional Research and Analysis, 2010; Bonnie, 2010). If wage formation is solely determined by the two parties then it is possible that employers would take unilateral decisions, particularly where the workers belong to disadvantaged communities with low skill levels and virtually no alternative choices for making a living. Ensuring fair wages for domestic workers can make a difference in the lives of the large number of women workers and their families. In Viet Nam, where the domestic work sector has been growing with the growth of middle income households in urban areas, the government has provided a separate notification of minimum wages to the domestic workers in 2014 with clear job specifications and certain other minimum protections so that these workers are not exploited (ILO, 2014).

Wage regulation should not be addressed in isolation but has to be intrinsically linked to working time standards and standards on wage protection. Setting a minimum wage for domestic workers is likely to remain ineffective as an intervention to prevent exploitation and ensure a decent living for the worker and his/her family if it is not appropriately linked to working time. For example, the 2013 constitutional reform regarding domestic work in Brazil introduced new rights for domestic workers, such as the right to overtime pay, a maximum eight hour working day and 44 hour working week, to complement the already existing minimum wage coverage (ILO, 2013b).

\footnotetext{
These countries include France, Germany and Italy.

These estimates provide the extent of legal coverage rather than compliance with the legal requirements.
} 
The Domestic Workers Convention No. 189 and its supplementing Recommendation No. 201 address important gaps in the body of international labour standards with regard to domestic workers' wages and working time (Oelz, 2014). The ILO's main instruments on minimum wage fixing, the Minimum Wage-Fixing Convention, 1928 (No. 26) and the Minimum Wage Fixing Convention, 1970 (No. 131) have left coverage of domestic workers at the discretion of ratifying States. ${ }^{6}$ By contrast, Article 11 of Convention No. 189 requires ratifying States to take measures "to ensure that domestic workers enjoy minimum wage coverage, where such coverage exists, and that remuneration is established without discrimination based on sex". The provision implies that countries ratifying for the fixing of minimum wages need to ensure that the system covers domestic workers. Under Article 11 it is possible to cover domestic workers by a national minimum wage but also by sectoral or occupational minimum wage rates. The inclusion of a clause concerning non-discrimination could also address the risk of gender-based undervaluation of domestic work (Oelz, 2014). As indicated in an informal opinion prepared by the International Labour Office in July 2012 in response to a clarification request from the Government of Peru,

"the Convention calls for measures to ensure minimum wage coverage for domestic workers without specifying however whether this should entail extending the national minimum wage to cover domestic workers or possibly fixing a separate minimum wage rate specifically for this occupational category...There is nothing in the Convention that prevents national authorities from establishing differentiated minimum wage rates for domestic workers provided that the principle of equal remuneration for work of equal value is fully observed and particular attention is given to eliminating de facto as well as de jure discrimination, for example, by ensuring that domestic work is not undervalued due to gender stereotypes"(ILO, 2014c, at footnote 109).

Another area where Convention No. 189 has added protective standards for domestic workers is concerning payments in kind. While domestic workers can be excluded from the rules on this subject under Protection of Wage Convention, 1949 (No. 95), by virtue of its Article 2(2), countries ratifying Convention No. 189 are required to ensure that only "a limited proportion of the remuneration of domestic workers" can be paid in the form of in-kind payment (Article 12). As regards working time, Article 10 of the Convention calls for measures towards ensuring equal treatment of domestic workers and other workers as regards several dimensions of working time. Most importantly, these provisions imply that domestic workers, including those living in the household for which they work, have the right to an arrangement under which a distinction is made between working time (including overtime hours) and nonworking time. This principle is crucial for setting and ensuring fair remuneration for domestic workers, and for the recognition of domestic workers as workers with dignity.

While Convention No. 189 establishes the principle of inclusion of domestic workers under minimum wage coverage as an international standard, individual countries seeking to imple-

\footnotetext{
For instance, though domestic workers are now covered by the national minimum wage in France, "domestic servants" and janitors were the only groups initially excluded by the government from the application of Convention No. 131, Article 1(3) on the ground that "it is impossible to work out exactly how many of their hours of presence are actual working hours" (ILO, 1975, p. 100). Only when a national collective agreement for domestic workers establishing legally binding wage minima came into effect, the government also included domestic workers under the national minimum wage.
} 
Table 7: Coverage for domestic workers in minimum wage legislation (2015)

\begin{tabular}{|c|c|c|}
\hline & General workers & Workers in domestic work \\
\hline Brazil & $\begin{array}{l}\text { National minimum wage is applicable } \\
\text { to all workers in the private sector }\end{array}$ & $\begin{array}{l}\text { National minimum wage applicable to } \\
\text { domestic workers }\end{array}$ \\
\hline Costa Rica & $\begin{array}{l}\text { National minimum wage floor and a system } \\
\text { of (higher) occupational rates }\end{array}$ & $\begin{array}{l}\text { National minimum wage floor applicable to } \\
\text { domestic workers, in combination with a } \\
\text { specific (higher) occupational rates }\end{array}$ \\
\hline Mexico & General minimum wage & $\begin{array}{l}\text { Applies to domestic workers ( } 2 \text { rates for } \\
\text { different geographical regions) }\end{array}$ \\
\hline Peru & $\begin{array}{l}\text { General minimum wage and a complex } \\
\text { system of determining rates for certain } \\
\text { occupational categories }\end{array}$ & Domestic workers excluded \\
\hline Turkey & National minimum wage & $\begin{array}{l}\text { National minimum wage applicable to } \\
\text { domestic workers }\end{array}$ \\
\hline Viet Nam & $\begin{array}{l}\text { Minimum wages are set for two broad } \\
\text { categories of workers and set separately } \\
\text { for different regions }\end{array}$ & $\begin{array}{l}\text { The (general) regional rates are applicable } \\
\text { to domestic workers, and this has been more } \\
\text { clearly specified as of May } 25^{\text {th }}, 2014\end{array}$ \\
\hline India & $\begin{array}{l}\text { Central Government sets } 45 \text { minimum wage } \\
\text { rates and there are } 1679 \text { occupational } \\
\text { categories which are covered under schedules } \\
\text { of employment }\end{array}$ & $\begin{array}{l}\text { Domestic work minimum wage rates were } \\
\text { set in in Andhra Pradesh, Bihar, Kerala, } \\
\text { Karnataka, Jharkhand, Odisha and Rajasthan } \\
\text { schedules of employment }\end{array}$ \\
\hline Philippines & $\begin{array}{l}\text { Minimum wages are set on a sectoral basis } \\
\text { by regional wage boards }\end{array}$ & $\begin{array}{l}\text { Regional rates for domestic workers set by } \\
\text { acts of Parliament, most recently in the } 2013 \\
\text { Domestic Workers Act }\end{array}$ \\
\hline South Africa & $\begin{array}{l}\text { Minimum wages are set for } 11 \text { economic } \\
\text { sectors under the Basic Conditions } \\
\text { of Employment Act, through Sectoral } \\
\text { Determinations }\end{array}$ & $\begin{array}{l}\text { Domestic workers' minimum wages are set } \\
\text { by Sectoral Determination No. } 7 \text { ( } 2 \text { rates for } \\
\text { different geographical regions) }\end{array}$ \\
\hline Mali & $\begin{array}{l}\text { National minimum wage floor for all sectors } \\
\text { other than domestic workers }\end{array}$ & $\begin{array}{l}\text { Domestic workers are covered by separate } \\
\text { rates for seven categories of domestic } \\
\text { workers (corresponding to level of } \\
\text { qualifications) }\end{array}$ \\
\hline Indonesia & Sectoral and provincial level minimum wage & Domestic workers not covered \\
\hline
\end{tabular}

ment it need to decide which type of minimum wage setting for domestic workers is most effective in their circumstances. While there is no one single approach, it would be useful for countries to look at the different country practices on design and implementation of minimum wage policies for domestic workers and assessing how these polices have evolved over time. If we examine the 11 countries under analysis, a varied picture emerges with regard to the design of minimum wage policy for domestic workers (table 7). This illustrates that national regula- 
tory regimes have responded in different ways - or not - to the need to set minimum wages for domestic workers. In all of the countries examined there is no collective bargaining in the domestic work sector although in several of them domestic workers trade unions exist (e.g. India, Mexico, South Africa and Peru). In Brazil, Mexico and Turkey domestic workers are covered by the national minimum wage, with no distinction being made between domestic workers and other workers. In Viet Nam, the regional minimum wage rates were extended to domestic workers, and since 2014 there is a separate notification, which provides more details about the tasks that are performed by domestic workers. In Mali, domestic workers are not covered by the otherwise all-encompassing national minimum wage, and there exists a scale of seven different rates for domestic workers based on their qualification levels (the lowest rates is below the national minimum wage and the highest is substantially above the national minimum wage).

In Costa Rica, in addition to the national minimum wage floor, which covers domestic workers, rates for domestic workers are set on an occupational basis. By contrast, India's complex rates structure under the Minimum Wage Act 1948 does not offer an inclusive national floor nor does it schedule domestic work as an occupation for which minimum wages should be set (Belser and Rani, 2011). Nevertheless, the central government has left it to the discretion of respective state governments to include domestic workers into minimum wage coverage at the state level and a number of them have done so much more recently (table 7). The schemes in South Africa and the Philippines are similar in the sense that both countries set minimum wages on a sectoral basis, including domestic workers, while also determining rates for different regions. Finally, Indonesia and Peru did not provide minimum wage coverage for domestic workers. As a result, most countries have complete coverage of domestic workers by minimum wage legislation, while in India they are only partially covered depending upon the initiatives taken by the respective states. At the state level, domestic workers were included as a "schedule of employment" only since 2007. By 2009 about four states (Andhra Pradesh, Karnataka, Bihar and Rajasthan) had included them in the legislation. As a result, in 2009-10 only 14.7 per cent of the domestic workers were covered by minimum wage legislation.

\section{Disparity in minimum wage setting}

Setting minimum wages for domestic workers is prone for reproducing existing undervaluation of this type of work in the labour market, if not carefully monitored. If a national minimum wage is set for all workers in a meaningful way, including domestic workers, then this risk is not attenuated and could have an impact on gender pay gaps (Rubery, 2003). However, in countries where minimum wages are set on a sectoral or occupational basis, it is very important to understand the factors that have contributed to the setting of the rates. This is also relevant for countries that have systems that combine a national minimum wage with occupational rates such as Costa Rica. An occupational rate for domestic workers can potentially be useful, as it makes up for the absence of collective bargaining, but, it is essential that it is set at an appropriate level.

For a selection of countries we try to see the disparity in minimum wage rates between domestic workers and workers in other sectors (table 8). In the Philippines we find that the monthly minimum wage of domestic workers was one-fifth of those workers in the non-agricultural sector in the national capital region in 2013. In Mali minimum wages are sub-divided for seven categories of domestic workers and the lowest category gets two-thirds of the wages of the 
Table 8: Gendered disparity in minimum wage rates (nominal) in select countries, latest year available

\begin{tabular}{|c|c|c|}
\hline Country & Domestic work & $\begin{array}{l}\text { Other sectors/national } \\
\text { minimum wage }\end{array}$ \\
\hline $\begin{array}{l}\text { Philippines } \\
\text { (monthly, National Capital } \\
\text { Region) }\end{array}$ & P 2,500 & $\begin{array}{l}\text { P } 12,116 \\
\text { for non-agricultural workers }\end{array}$ \\
\hline $\begin{array}{l}\text { Mali } \\
\text { (monthly) }\end{array}$ & $\begin{array}{l}\text { From F } 21.936 \text { (category I) } \\
\text { to F } 35.049 \text { (category VII) }\end{array}$ & $\begin{array}{l}\text { National minimum wage } \\
\text { is } 28.460\end{array}$ \\
\hline $\begin{array}{l}\text { Costa Rica } \\
\text { (monthly) }\end{array}$ & C $169,142.26$ & $\begin{array}{l}\text { C } 283,799.64 \\
\text { (non-qualified workers) }\end{array}$ \\
\hline $\begin{array}{l}\text { South Africa } \\
\text { (hourly, Area A) }\end{array}$ & R 10.59 & $\begin{array}{l}\text { R } 16.98 \text { in the contract } \\
\text { cleaning sector }\end{array}$ \\
\hline $\begin{array}{l}\text { India } \\
\text { (daily) }\end{array}$ & & Cleaning workers \\
\hline Karnataka & 165.58 & 195.38 \\
\hline Andhra Pradesh & 173.85 & 260.56 \\
\hline Bihar & 144.62 & 157 \\
\hline Rajasthan & 144.73 & 147 \\
\hline
\end{tabular}

highest category. Interestingly, the minimum wages for the lowest category is lower than that of the national minimum wages. In Costa Rica and South Africa the monthly or hourly minimum wage of the domestic worker is only 60 per cent of that of a general non-qualified worker or contract cleaning sector worker, respectively. In India, the minimum wages for domestic workers in all the states where it is introduced is lower than the cleaning workers who are lowest paid. The question that is intriguing is what explains such a huge disparity in the minimum wages for domestic workers compared to other workers, especially keeping in mind that the very purpose of minimum wage setting is to increase earnings for those at the bottom of the income distribution. This issue needs further exploration and is beyond the scope of this paper.

\section{Extent of minimum wage compliance and extent of violation}

Legislation of minimum wages for domestic workers need not translate into workers enjoying the benefits from it. A central issue pertains to the translation of the legislation into actual practice, awareness of such laws among the general public and its effective implementation. The effectiveness of a minimum wage policy can be measured through the extent to which the 
employers comply with the law. There are number of ways in which compliance can be measured: first, by looking at the number of complaints made by workers in the judicial system; second, through examining data on work place inspections; and third, by calculating the proportion of workers who are receiving minimum wages, which is a statistical measure (see Rani et al., 2013, for details). For this paper, we use the statistical measure and calculate compliance as the percentage of domestic wage earners getting paid more than the minimum wages prescribed in each country for different categories of work within the domestic work sector.

It is important to remember that the degree of compliance depends upon the complexity of the minimum wage system and the level at which the minimum wage is set. Further more, it is also linked to the general institutional environment (Marinakis, 2014). The rate of compliance for domestic workers is comparatively lower as it ranges between 9.3 per cent (Turkey) and 100 per cent (Philippines) for the latest available year (table 9). For all workers, the rate of compliance ranges between 95 per cent in Viet Nam to 49 per cent in Indonesia and Turkey (Rani et al., 2013). Philippines exhibits 100 per cent compliance as the minimum wages at the time of the analysis had not been updated for a long period and hence the rates were too low and had lost their relevance. Similarly, the compliance rate in Mexico and Viet Nam is comparatively high, which could be due to the low level at which the minimum wage is generally set in these two countries. In some of the countries minimum wages for domestic workers are far lower than the national minimum wages or other occupational minimum wages, as observed earlier. Despite this lower level, still a large proportion of the workers do not receive the full minimum wages, and compliance is lower in rural areas than in urban areas. Over a period of time, compliance rates have improved in some countries (Mali, South Africa) while they have deteriorated in others (Brazil, Mexico, Viet Nam).

Table 9: Minimum wage compliance among domestic workers and all workers

\begin{tabular}{|c|c|c|c|c|c|c|c|c|c|c|c|c|}
\hline & \multicolumn{6}{|c|}{ Mid-2000s } & \multicolumn{6}{|c|}{ Latest available year } \\
\hline & \multicolumn{3}{|c|}{ Domestic workers } & \multicolumn{3}{|c|}{ All workers } & \multicolumn{3}{|c|}{ Domestic workers } & \multicolumn{3}{|c|}{ All workers } \\
\hline & Rural & Urban & All & Rural & Urban & All & Rural & Urban & All & Rural & Urban & All \\
\hline Brazil & 41.2 & 51.6 & 50.4 & 64.3 & 85.7 & 83.4 & 35.3 & 41.5 & 40.9 & 61.4 & 81.9 & 79.8 \\
\hline Costa Rica & 22.1 & 27.1 & 25.1 & 48.6 & 66.0 & 59.6 & 15.7 & 30.4 & 25.4 & 56.7 & 72.0 & 67.1 \\
\hline India & - & - & - & 26.4 & 53.6 & 31.9 & 18.6 & 43.7 & 36.8 & 49.8 & 84.7 & 61.0 \\
\hline Mali & 15.6 & 6.3 & 7.1 & 61.0 & 57.8 & 58.6 & 0.0 & 49.3 & 36.6 & 70.9 & 84.4 & 79.3 \\
\hline Mexico & - & - & 74.5 & - & - & 91.3 & - & - & 71.0 & - & - & 90.6 \\
\hline Philippines & - & - & 100 & - & - & 56.6 & - & - & 100 & - & - & 56.2 \\
\hline $\begin{array}{l}\text { South } \\
\text { Africa }\end{array}$ & - & - & 38.7 & - & - & 56.4 & 25.7 & 48.9 & 44.2 & 34.6 & 58.6 & 52.9 \\
\hline Turkey & - & - & - & - & - & 69.6 & 3.2 & 10.1 & 9.3 & 38.4 & 52.8 & 50.1 \\
\hline Viet Nam & 89.2 & 91.2 & 90.0 & 92.7 & 98.1 & 95.0 & 92.6 & 79.2 & 86.5 & 94.5 & 96.1 & 95.2 \\
\hline
\end{tabular}


Table 10: Extent of violation of non-payment of minimum wages among domestic workers

\begin{tabular}{lllllll}
\hline & \multicolumn{7}{c}{ Mid-2000s } & \multicolumn{5}{c}{ Latest available year } \\
\cline { 2 - 6 } & Rural & Urban & All & Rural & Urban & All \\
\hline Brazil & 0.55 & 0.46 & 0.47 & 0.57 & 0.46 & 0.47 \\
Costa Rica & 0.44 & 0.49 & 0.47 & 0.53 & 0.47 & 0.49 \\
India & - & - & - & 0.47 & 0.40 & 0.43 \\
Mali & 0.56 & 0.71 & 0.69 & 0.55 & 0.52 & 0.53 \\
Mexico & - & - & 0.37 & - & - & 0.36 \\
Philippines & - & - & - & - & - & - \\
South Africa & - & - & 0.36 & 0.47 & 0.36 & 0.40 \\
Turkey & - & - & - & 0.53 & 0.42 & 0.44 \\
Viet Nam & 0.25 & 0.21 & 0.23 & 0.27 & 0.21 & 0.23 \\
\hline Source: Authors' estimates based on household and labour force surveys of the respective country. & &
\end{tabular}

From a policy perspective, while we compute the level of compliance, it is also important to know the extent of violation by the employers. Is the proportion of the extent of violation marginal or quite large? The evasion could be deliberate or due to lack of awareness about the prevailing minimum wages, since these are often not widely publicized. For this purpose, we measure the extent of violation, which is the distance between the average wages earned by domestic workers earning below minimum wages and the actual minimum wages. The method we adopt is similar to that of Bhorat et al. (2012). Based on this method, we estimate that below-minimum wage workers on average earn 23 per cent less in Viet Nam and 53 per cent less in Mali than the applicable minimum wage for the latest available year (table 10). On average, in a majority of the countries under analysis, domestic workers earn 50 per cent less than the applicable minimum wages. These estimates are higher in rural areas compared to urban areas, which could be due to the particularly low probability of being inspected in the rural areas and the economic situation of rural households (table 10). Over time the extent of violation has remained almost the same in a majority of the countries. The depth of violation we find for Mali is consistent with the information on actual wages between $\mathrm{F} 4,000$ and $\mathrm{F} 10,000$ - received by domestic workers in the country reported by the Association de défense des droits des aides ménagères et domestiques (ADDAD), a local domestic workers association created in $2011 .^{7}$

See ADDAD's web blog at http://addad-mali.blogspot.fr/p/blog-page_14.html [accessed 10 June 2015]. 


\section{Designing minimum wage coverage for domestic workers}

Social attitudes to domestic work and domestic workers have resulted in lesser protection of domestic workers under labour laws. Where coverage exists it tends to offer lower levels of protection than for other workers, particularly with regard to wages and working time (ILO, 2013a). However, a growing number of countries have made policy interventions to secure fair and decent working conditions for domestic workers, as suggested by the pertinent international labour standards. Domestic work is an economic sector in which large numbers of women seek to make a living and if their incomes and social conditions were to be improved, then overall income inequality would be reduced. Improving wages for domestic workers along with improving their training and skills would enable them to access higher incomes while at the same time providing better services for households.

While the ILO standard-setting process has facilitated a shift in positions of a critical mass of policy makers, changing public opinion at the national and local levels in favour of new initiatives to promote decent work for domestic workers, however, remains a challenge. The hesitation with regard to extending minimum wage coverage could be due to a number of reasons: actual wages of domestic workers are much lower compared to other workers hence the inclusion into the national minimum wage does not seem realistic $;^{8}$ minimum wages for domestic workers are seen as running counter to the interests of those who employ domestic workers; fears that increased costs for domestic work will deprive households of the much needed services, particularly care, as public care policies are weak; a perception that a legal minimum wage would increase informality or destroy jobs; setting minimum wages is viewed as inappropriate because the State enforcement is seen as interfering into the privacy of the household. Thus, successfully regulating wages for domestic workers requires policy makers to address a set of complex social, political and technical issues. However, despite this complexity some countries have more recently engaged in reforms of minimum wage policies for domestic worker and we look at some of the challenges they faced and the options they considered.

For countries that set a national minimum wage, the natural entry point will be to consider including domestic workers under its coverage. The mechanism for doing so will depend on the level of the existing minimum wage and the actual wage levels for domestic workers. When actual wage levels are too far below the existing national minimum wage, then minimum wages for domestic workers can be progressively increased over a period of time. For example, in Chile, where a national minimum wage exists, and a separate minimum wage for domestic workers was operated at 75 per cent of the national minimum wage. However, Chile has progressively extended the full national minimum wage to domestic workers through a series of scheduled annual increases between 2009 and 2011. More recently, in 2014, also amended the Labour Code to exclude payments in kind below the minimum wage level. ${ }^{9}$

\footnotetext{
The underlying concern being that a meaningful coverage of all workers may not be feasible in such situation: a unified wage would be too high for the domestic work sector or too low for other sectors.

9 Law No. 20.786 of 27 October 2014 modifying the daily hours, rest and composition of the remuneration of domestic workers and prohibiting requirements for wearing uniforms in public, available at http://www.leychile.cl/ Navegar?idNorma=1068531 [accessed 10 June 2015].
} 
Similarly, in Argentina, where a separate rate for domestic work is set by ministerial decree, that rate was progressively raised to the level of the national minimum wage (Oelz, 2011). In Cape Verde, which introduced a national minimum wage for the first time in 2014, it was decided not to exclude domestic workers although employers are allowed to reduce monetary payments below the minimum wage level for provision of food and accommodation. Minimum wage coverage for domestic workers has been probably the most disputed issue in Peru's review of national law and practice with a view to a possible ratification of Convention No. 189, with key stakeholders disagreeing whether minimum wage coverage should be achieved through inclusion in the national minimum wage or by a separate (lower) rate for domestic workers (Fuertes Medina et al., 2013).

Where countries use systems relying primarily on sectoral or occupational minimum wage rates or decide to set a separate minimum wage for domestic workers apart from a national minimum wage, particular care should be taken to avoid gender-based undervaluation of domestic work. In case of Peru, as mentioned above in section 3.1., the ILO advised that Convention No. 189 did not per se exclude the possibility of setting a separate rate for domestic workers, but it cautioned that there should not be any direct or indirect discrimination and to ensure that the principle for equal work for work of equal value is respected. ${ }^{10}$ In the Philippines, the government, when developing the Domestic Workers Act 2013 and seeking to reform domestic workers minimum wages, relied on data analysis and dissemination with regard to the profile of the employers of domestic workers and the actual working conditions of domestic workers in order to counter the argument that raising the minimum wage would result in job losses (ILO, 2011). While the sectoral wage level for domestic workers remains considerably below minimum wages for other workers in the Philippines, the new legislation provides for a new role of the Regional Tripartite Wage Boards to review and adjust the wage rate periodically, ${ }_{11}^{11}$ a process that is currently under preparation and could be used to progressively decrease minimum wage disparity.

\section{Improving compliance}

Social attitudes regarding domestic work and domestic workers are not only influencing the extent of legal protection but also compliance levels. As shown in this paper, domestic workers, a majority of whom are women, are not only often lacking minimum wage coverage but they are also more affected by non-compliance where coverage exists, thus facing a double disadvantage. It is also revealing that the empirical evidence presented in this paper shows that the level at which the minimum wage is set does not seem to be a determinant of the level of non-compliance, nor is the type of rates. The existence of widespread noncompliance, however, suggests that achieving compliance in domestic work is a complex matter that calls for comprehensive strategies rather than conventional wisdom that calls for

\footnotetext{
10 In Austria, the legislation governing minimum wage setting for domestic workers to use the wage rates applicable to comparable sectors of the economy as a point of reference (Work Constitution Act, section 23). While this can help to orient wage for domestic workers by using care jobs for non-household employers as references, the practice does not challenge undervaluation of care work more generally.

11 Domestic Workers Act, section 24.
} 
enhancing sanctions, complaints mechanisms and labour inspections, though these measures are also needed. Bamu (2013) has used four guiding questions to examine compliance and enforcement in the domestic work sector in South Africa: (1) What prevents the employers from fulfilling their obligations? (2) What prevents domestic workers from vindicating their rights? (3) How effective are the regulatory framework and the institutions enforcing it? (4) What is the impact of the lack of effective organizations of domestic workers? These questions provide useful entry points for analyzing and searching solutions for improved compliance in the domestic work sector.

In spite of regulation of domestic work that may exist, employers of domestic workers and workers themselves will often not see their arrangements as an employment relationship. Non-compliance may not be perceived as unlawful given that in practice many households continue to see domestic work basically being a private or family matter. There may be little initiative on the part of households to actively seek information on their legal obligations as employers or to formalize the employment relationship through a written contract. As observed by the Mexican National Council for the Prevention of Discrimination, the stereotype that it was "normal" for women with a certain ethnic and social background to be domestic workers because this is "what they know and able to do" is reflective of the low level of social recognition of domestic work which also influences levels of remuneration (CNPD, 2010). On their part, the domestic workers are often unable individually to challenge entrenched behavioural patterns, including non-compliance, due to social-cultural factors and lack of bargaining power, even if they are aware of existing legal protection.

For an individual worker to insist on the legal minimum wage rather than accepting the "prevailing market wage" depends particularly on the labour market situation. If labour supply is virtually unlimited, then in such cases workers prefer to have some wage rather than being unemployed. Often the relationship between domestic workers and their employers are personalized with emotional ties and support in times of need, which can make it difficult for domestic workers to insist on their rights. Seeking the support from "outside", including from unions and from labour inspectorates, to address non-compliance is often not the chosen path. Individual empowerment of domestic workers could only be facilitated by collective organization. A growing number of domestic workers associations and unions play a positive role allowing domestic workers to break their isolation and learn about and understand their rights, and in making domestic work and its contributions to society more visible. For example, in Mali, the Association de défense des droits des aides ménagères et domestiques founded in 2011 has become a visible civil society actor claiming respect for domestic workers' rights, including the enforcement of minimum wages laid down in the 1996 implementing decree to the Labour Code. In October 2013, the International Domestic Workers Network became a new global union federation, the International Domestic Workers Federation. However, examples in Germany, France and Uruguay show that such organizations can play a key role in shaping working conditions policies and promoting compliance, including that of minimum wages.

Convention No. 189 puts forward a holistic approach to compliance that emphasizes formalization of the employment relationship, and the empowerment of workers. It calls for the provision to the workers of a written contract, on terms and conditions of employment, including working hours and remuneration. This can help to establish a clear understanding between employer and workers of their mutual rights and obligations and basis for discuss- 
ing disagreements should they arise. Having a written contract empowers the worker in the employment relationship. Supplementing the Convention, Recommendation No. 201 outlines a range of measures than can be taken to better inform workers and employers of applicable rules and regulations and recommends the use of written pay slips and time records. These two instruments highlight the role that workers' and employers' organizations can play in promoting decent work for domestic workers.

Methods used more recently to tackle compliance gaps include the issuing of model contracts, offering accessible information materials on labour rights for domestic workers and targeted outreach campaigns (e.g. awareness raising activities in malls and parks). Some countries have introduced requirements for written contracts and contract registration and record keeping. For example, in the Philippines, the 2013 Domestic Workers Act imposes an obligation on the Department of Labour to develop and implement a continuous information dissemination programme in collaboration with a range of stakeholders and to develop a model contract. The labour authorities can request employers of domestic workers to furnish a copy of the contract and payslips in case of a complaint and also play a role in dispute settlement. However, the Act also mandates the local governments to play a role in promoting compliance with the laws governing domestic work, including through establishing contract registries and raising public awareness.

In addition to promoting an environment that favours compliance, the Convention also addresses the issues of access to justice and the role of public enforcement bodies. The general obligation under the Convention is for ratifying countries to establish "means of ensuring compliance with national laws and regulation for the protection of domestic workers". In terms of complaints-driven mechanisms and access to justice, Article 16 requires measures to ensure domestic workers' "effective access to court, tribunals or other dispute resolution mechanisms", while Article 17(1) calls for "effective and accessible complaints mechanisms", a notion that includes administrative procedures. In addition, the Convention calls for "measures for labour inspection", which refers to the whole range of measures that labour inspectorates may take, from providing information and protection to enforcement and inspection visits (Article 17(2)). The Convention's provisions on labour inspection considers both the need to protect households from arbitrary state interference, while at the same time providing for a role of labour inspectorates when it comes to ensuring compliance with laws regulating domestic work. By referring back to compatibility with national laws and regulations in relation to home visits, the Convention provides space for ratifying States to properly balance privacy of the home with the protection of workers' rights, so that any arbitrary or unlawful state interference in the private sphere is avoided.

In several countries with experience in using labour inspection (including inspection visits) for the protection of domestic workers' rights, the issue of access to households has been addressed through methodologies that rely on seeking the consent and cooperation of the occupant of the premises or on judicial authorization for entry. In Ireland, the National Employment Rights Agency (NERA) implemented a pilot programme on domestic workers in 2012, which involved meeting employers to check employment records in the household or an alternative meeting place (ILO, 2012). Similarly, in South Africa the labour inspection services relied on household visit campaigns targeting selected neighborhoods (Sjöberg, 2011). In countries such as Costa Rica, Brazil or Uruguay, the labour inspectorates have developed specialized tools to disseminate information and facilitate their work in respect to domestic 
work in the form of dedicated websites, manuals and inspection protocols. ${ }^{12}$ With compliance only marginally improving in Costa Rica and decreasing in Brazil (table 8), further measures are needed to tackle the problem. The experience in Uruguay has shown that improving coverage under labour laws and enforcing them can go hand in hand with a progressive formalization of the sector, with inspectorates playing an important role in this respect, through their visits of thousands of households for verifications (ILO/FORLAC, 2015).

Building on the experiences of other countries in the region, Chile's 2014 labour law reform on domestic work strengthened the role of the labour inspectorate by provisions that require the employer to submit the signed employment contract to the labour inspectorate, electronically or in person. This is to facilitate determination of the existence of an employment relationship and also to locate the place of work. Labour inspectors can present themselves at private homes, with employers having the choice of receiving the inspector or making an appointment at the labour inspectorate for the checking of required documentation. The inspectorate is also mandated to submit registered contracts to the courts in case of disputes. ${ }^{13}$ Full implementation of these measures will be crucial to reverse the increase in non-compliance observed in parallel to the incremental increase of the minimum wage between 2009 and 2011. During this period the number of domestic workers receiving less than the minimum wage increased from 24,194 to 48,315 . The increase was largely due to non-compliance in urban areas, remarkably in a context of overall wage growth (Velásquez, 2014). Interestingly, in Europe most labour inspectorates remain without a particular focus on domestic work, despite the EU Fundamental Human Rights Agency (FRA) highlighting the important role of labour inspection with regard to addressing labour exploitation of domestic workers. The FRA recently noted that "severe exploitation of domestic workers is often fostered by a complete lack of monitoring, as a result of legal regulations preventing monitoring, the hidden workplace and multiple forms of dependency of the worker on the employer" (FRA, 2015, p.51).

\footnotetext{
12 See e.g. the Brazilian labour inspectorate website on domestic work, at http://portal.mte.gov.br/trab_domestico/comissao-do-trabalho-domestico; [accessed 10 June 2015]. As regards Uruguay, see OIT, Manual de buenas prácticas para trabajadoras y empleadoras del servicio doméstico, Santiago, Organización Internacional del Trabajo, 2013.

13 Article 146ter of the Labour Code as revised by Act No. 20.786 (see above note 9).
} 


\section{Concluding considerations}

Minimum wages for domestic workers need to be seen in the broader context of gender equality and women's participation and situation in the labour market. Low pay and high informality affect women in sectors other than domestic work, though the effects of genderbased undervaluation appear to be higher in domestic work, likely due to its gendered nature and the use of in-kind benefits such as food and accommodation as compensation, particularly in the case of live-in workers. Low pay in domestic work resulting from gender-bias may also be contributing to low pay in other female-dominated sectors. Lack of recognition of paid and unpaid domestic work could also be a structural factor behind discrimination of women in the labour market. Future research could examine how women's wages in other low-skill sectors evolve in countries that set up a minimum wage setting. It would also be useful to explore further how the lessons learned regarding improving working conditions in domestic work could be relied upon for addressing informality and low pay in other female-dominated sectors, such as agriculture or home-based work.

It is often argued that minimum wages rates should not be set too high as this would merely lead to more non-compliance. We argue that minimum wages should be set at a realistic level, but need to be sufficiently ambitious to fulfil their redistributive role, while being backed up with comprehensive compliance strategies. This is even truer for the domestic work sector. While the financial capacity of the employer is a valid consideration, it should also be kept in mind that non-compliance in domestic work may be more frequent than in other sectors and could be influenced by social attitudes, perceptions of the value of the work, and discrimination rather than actual financial capacity and objective evaluation of the job content. Our empirical findings also indicates that non-compliance in domestic work is not a strict function of the level at which the minimum wage is set.

Including domestic workers into national minimum wages also ensures inclusiveness and recognition of domestic workers. Some countries that previously had set separate lower minimum wage rates have shown that domestic workers rates can be gradually brought up to the national floor, such as in Chile or Argentina. So, when it comes to the setting of sectoral or occupational rates for domestic workers, specific attention is needed so that their work is not undervalued, and the involvement of the two parties (workers and employers) in the minimum wage fixing process (for example, Uruguay) would ensure that their work is respected. It is also important to take into consideration the economic situation of the employing households, which in some cases could be done through setting differentiated rates by geographic area.

Particularly in countries where the demand for domestic work is increasing - which tends to be the case when there is economic growth as well as an increase in the numbers of middle class households. This situation is an opportunity to introduce or improve minimum wage and other social protection policies for domestic workers. Indeed, in such a context, minimum wages and their enforcement, along with better matching of demand and supply are tools to ensure that increased demand translates into higher wages for workers rather than increased benefits for informal and unregulated labour brokers. This is a relevant consideration particu- 
larly in the domestic work sector, which is characterized by a high prevalence of internal and international migration.

Ensuring compliance requires proactive action for widespread dissemination and awareness rising on existing rates and sanctions for non-compliance, as well as promotion of formalization of the employment relationship. In order for sanctions to be dissuasive employers will have to perceive a reasonable chance of "being caught". Hence, some form of monitoring or inspection is indispensable. Ensuring visibility and transparency is a first step in this regard, e.g. through contract registration, time record pay slips or requiring electronic payments. However, because of the characteristics of domestic workers and employers in this sector and the social-cultural underpinnings described in this paper, for compliance strategies to be successful, the overall approach for this sector needs to move along from a welfare-oriented to a rights-based approach that increases choices and provides freedom for these workers. Individual empowerment, including through access to training and skills development, and collective organization play a key role in this regard. 


\section{References}

Abramo, L., and Valenzuela, M. E. 2005. "Women's labour force participation rates in Latin America" in International Labour Review, Vol. 144, No. 4, pp. 369-400.

Bamu, P. 2013. "Nurturing a culture of compliance with domestic workers' rights in South Africa" in D. du Toit (ed.): Exploited, undervalued - and essential: Domestic workers and the realization of their rights (Pretoria University Law Press), pp. 157-212.

Belser, P., and Rani, U. 2011. "Extending the coverage of minimum wages in India: simulations from household data" in Economic and Political Weekly, Vol. 56, No. 20, 47-55.

Bhorat, H.; Kanbur, R. and Mayet, N. 2010. "Minimum violation in South Africa" in International Labour Review, Vol. 151, No. 3, pp. 288-287.

Bonnie, A. 2010. "Trabajadoras domésticas nicaragüenses en Costa Rica: un tortuoso camino hacia el reconocimiento" in Encuentro, Year XLII, № 87, pp. 75-88.

Consejo Nacional para prevenir la Discriminacion (CNPD). 2012. Derechos iguales para las trabajadoras del hogar en Mexico, Marzo. Available at: http://www.conapred.org.mx/ documentos_cedoc/Trabs-Hogar-DI-2012_ACCSS.pdf [accessed on 1 June 2015].

European Union Agency for Fundamental Rights (FRA). 2011. Migrants in an irregular situation employed in domestic work: Fundamental rights challenges for the European Union and its Member States. Vienna

FRA. 2015. Severe labour exploitation: workers moving within or into the European Union States' obligations and victims' rights. Vienna.

Fuertes Medina, P., Rodriguez, E. and Casali, P. 2013. Trabajo doméstico remunerado en el Perú. Situación y perspectivas en función del Convenio 189 y la Recomendación 201 de la OIT. Lima: OIT/ Oficina de la OIT para los Países Andinos. Available at: http://www.ilo.org/wcmsp5/groups/public/---americas/---ro-lima/documents/publication/wcms_213173.pdf [accessed on 1 June 2015].

Ganguli, I., Hausmann, R., and Viarengo, M. 2014. "Closing the gender gap in education: What is the state of gaps in labour force participation for women, wives and mothers?" in International Labour Review, Vol. 153, No. 2, pp. 173-204.

International Labour Organization (ILO). 1975. Summary of reports on ratified Conventions, Geneva. Available at: http://www.ilo.org/public/libdoc/ilo/P/09661/09661(1975-60). pdf [accessed 1 June 2015].

ILO. 1970. The employment and conditions of domestic workers in private households. ILO document D.11 1970. Geneva. Available at: http://www.ilo.org/public/libdoc/ ilo/1970/70B09_88_engl.pdf [accessed 1 June 2015].

ILO. 2009. Global Employment Trends for Women, Geneva.

ILO. 2010. Decent work for domestic workers. Report IV(1), International Labour Conference, 99th Session, 2010. Geneva. 
ILO. 2011. Domestic Workers in the Philippines: Profile and Working Conditions, Fact Sheet, 8 Nov. 2011. Available at: http://www.ilo.org/travail/whatwedo/publications/ WCMS_167021/lang--en/index.htm [accessed 1 June 2015].

ILO. 2012. Regional Knowledge-sharing forum Labour inspection and the domestic work sector, meeting document 12 Oct. 2012. Available at: http://www.ilo.org/labadmin/ info/WCMS_202400/lang--en/index.htm [Accessed 1 June 2015].

ILO. 2013a. Domestic workers across the world: Global and regional statistics and the extent of legal protection. Geneva

ILO. 2013b. Global Momentum grows for domestic workers legislation. Available at: http:// www.ilo.org/global/about-the-ilo/newsroom/news/WCMS_208727/lang--en/index.htm [Accessed 10 June 2015]

ILO. 2014a. Global Wage Report 2014/15: Wages and income inequality. Geneva.

ILO. 2014b. Domestic work is a professional job, 16 Apr. 2014. Available at: http://www.ilo. org/hanoi/Informationresources/Publicinformation/newsitems/WCMS_241180/lang-en/index.htm [accessed 10 June 2015]

ILO. 2014c. Minimum Wage Systems. General Survey of the reports on the Minimum Wage Fixing Convention, 1970 (No. 131), and the Minimum Wage Fixing Recommendation, 1970 (No. 135), International Labour Conference, 103rd Session, 2014, ILO, Geneva.

ILO/FOFRLAC. 2015. Promoción de la formalización del trabajo doméstico en Uruguay. Available at: http://www.ilo.org/wcmsp5/groups/public/---americas/---ro-lima/documents/publication/wcms_371217.pdf [Accessed 10 June 2015]

Kapsos, S., Silberman, A., and Bourmpoula, E. 2014. Why is female labour force participation declining so sharply in India?, ILO Research Paper No. 10, Geneva.

Marinakis, A. (ed.). 2014. Incumplimiento con el salario mínimo en América Latina. El peso de los factores económicos e institucionales. ILO, Santiago.

Nopo, H., and Hoyos, A. 2010. Evolution of gender wage gaps in Latin America at the turn of the twentieth century: An addendum to "New century, old disparities", IZA Discussion Paper No.5086, Bonn, IZA.

Oelz, M. 2011. Remuneration in domestic work. Domestic Work Policy Brief No. 1. Geneva, ILO.

Oelz, M. 2014. “The ILO's Domestic Workers Convention and Recommendation: A window of opportunity for social justice" in International Labour Review, Vol. 153, No. 1, pp. 143-172.

Rubery, J. 2003. Pay equity, minimum wage and equality at work, InFocus Programme on Promoting the Declaration on Fundamental Principles and Rights at Work, Working Paper, DECLARATION/WP/19/2003, Geneva, ILO.

Rubery, J., and Grimshaw, D. 2011. "Gender and the minimum wage" in S. Lee and D. McCann (eds.): Regulating for decent work: New directions in labour market regulations (Basingstoke and Geneva, Palgrave MacMillan and ILO).

Rani, U., Furrer, M., and Lavers, T. 2015. Employment patterns, poverty and income inequality, Chapter 2, World Employment and Social Outlook (ILO, Geneva), pp. 32-71. 
Rani, U., Belser, P., Oelz M., and Ranjbar, S. 2013. "Minimum wage coverage and compliance in developing countries" in International Labour Review, Vol. 152, No. 3-4, pp. 381-410.

Shree, M. 2012. "Female Tribal Migrants as Domestic Workers: A Study of Their Compulsions and Working Conditions" in Man \& Development, Vol. XXXVI, No. 1, March, 99. 45-66.

Sjöberg, E. 2011. Enforcement of laws and regulating domestic work: A case study of South Africa. Master thesis. Lund, University of Lund, Faculty of Law.

Society for Regional Research and Analysis. 2010. Migration of Tribal Women: Its Socioeconomic Effects - An in-depth Study of Chhatisgarh, Jharkhand, M.P and Orissa, October 2010, available at: http://planningcommission.nic.in/reports/sereport/ ser/ser_mig.pdf [accessed 1 June 2015].

United Nations Development Programme (UNDP). 2013. Humanity divided: Confronting inequality in developing countries (New York).

Velásquez, M. D. 2014. "Chile: Incumplimiento en un contexto de sostenida del salario mínimo" in Marinakis, A. (ed.): Incumplimiento con el salario mínimo en América Latina. El peso de los factores económicos e institucionales (ILO, Santiago), pp. 61-110. 


\section{Annex}

\section{Data sources and time period per country}

\begin{tabular}{|c|c|c|}
\hline Country & Data source & Years \\
\hline Brazil & Pesquisa Nacional por Amostra de Domicílios (PNAD), IBGE & 2005 and 2009 \\
\hline Costa Rica & $\begin{array}{l}\text { Encuesta de Hogares de Propósitos Múltiples, INEC for 2005; } \\
\text { Encuesta Nacional de Hogares (ENAHO), INEC for } 2010\end{array}$ & 2005 and 2011 \\
\hline India & Employment-Unemployment Survey, NSSO, Government of India & $2004-05$ and $2009-10$ \\
\hline Indonesia & $\begin{array}{l}\text { National Labour Force Survey (Survei Angkatan Kerja Nasional) } \\
\text { (SAKERNAS), BPS-Statistics }\end{array}$ & 2005 and 2009 \\
\hline Mali & Enquête Permanente Emploi Auprès des Ménages (EPAM) & 2004 and 2010 \\
\hline Mexico & Encuesta Nacional de Ocupación Y Empleo (ENOE), INEGI & 2005 and 2010 \\
\hline Peru & Encuesta Nacional de Hogares, INEI & 2005 and 2010 \\
\hline Philippines & Labour Force Survey, National Statistics Office & 2003 and 2009 \\
\hline South Africa & $\begin{array}{l}\text { Labour Force Survey, Statistics South Africa for 2007, Labour } \\
\text { Market Dynamics (LMD) Survey for } 2011\end{array}$ & 2007 and 2011 \\
\hline Turkey & Household Labour Force Survey, Turkish Statistical Institute & 2005 and 2011 \\
\hline Viet Nam & $\begin{array}{l}\text { Labour and Employment Survey, General Statistics Office, Ministry } \\
\text { of Planning and Investment }\end{array}$ & 2007 and 2011 \\
\hline
\end{tabular}




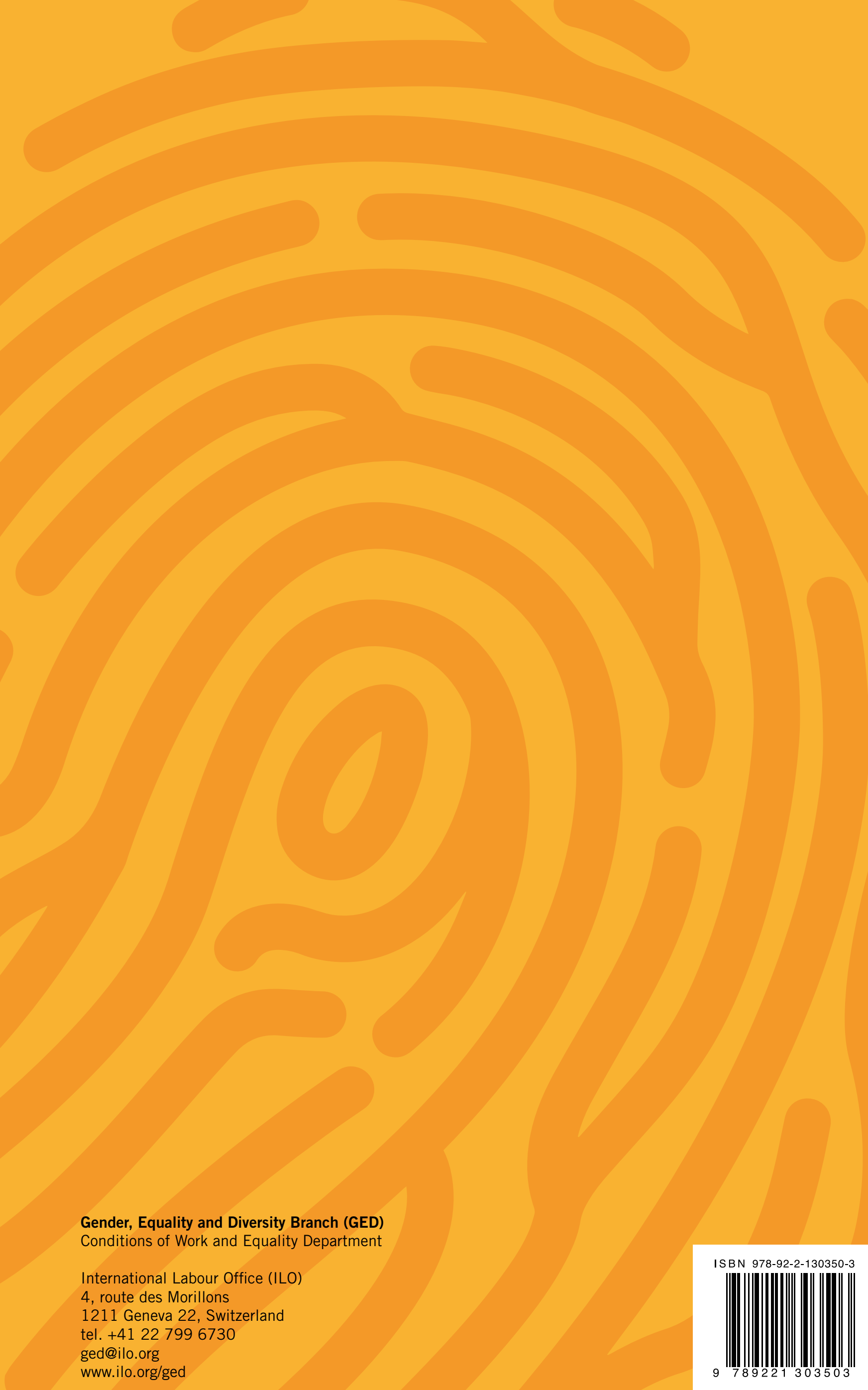

